\title{
Characteristics of the 16S-23S rRNA Intergenic Spacer Region of Mycoplasma haemomuris, Previously Classified as 'Haemobartonella muris'
}

\author{
Ryô HARASAWA ${ }^{1)}$, Makoto KAWAHARA ${ }^{2)}$ and Yasuko RIKIHISA ${ }^{3)}$ \\ ${ }^{1)}$ Animal Center for Biomedical Research, Graduate School of Medicine, The University of Tokyo, Bunkyo-ku, Tokyo 113-0033, ${ }^{21}$ Nagoya \\ City Public Health Research Institute, Nagoya 467-8615, Japan and ${ }^{3)}$ Department of Veterinary Biosciences, College of Veterinary \\ Medicine, The Ohio State University, 1925 Coffey Road, Columbus, Ohio 43210, U.S.A.
}

(Received 18 April 2002/Accepted 29 August 2002)

ABSTRACT. The intergenic spacer region between the 16S and 23S rRNA genes of Mycoplasma haemomuris, previously classified as 'Haemobartonella muris', was amplified by PCR and sequenced for analysis of the primary and secondary structures of the RNA transcript. The spacer region consisted of 219 base-pairs and lacked the spacer tRNA gene. A hypothetical secondary structure predicted in the RNA transcript of the spacer region was tentatively assigned boxA and box B loci peculiar to the members of the Mycoplasma. Mycoplasma haemomuris and the other species of the genus Mycoplasma are consistent with these characteristics of the spacer region. KEY WORDS: haemobartonella, mycoplasma, 16S-23S rRNA.

'Haemobartonella muris', an uncultivable haemotrophic bacterial species which infects murine erythocytes, has long been recognized as a member of the order Rickettsiales [8]. It was, however, more than 35 years ago that ' $H$. muris' was found to be cell wall-less and indistinguishable from mycoplasmas [19]. Phylogenetic analyses based on the 16S rRNA sequence revealed that ' $H$. muris', ' $H$. felis' and 'Eperythrozoon suis' are closely related to Mycoplasma species [15]. Similarly, 'E. wenyonii' was found to be genetically close to the genus Mycoplasma [13]. Therefore, it was recently proposed that the two genera, 'Haemobartonella' and 'Eperythrozoon', be transferred to the genus Mycoplasma $[11,12]$. To date no additional genetic comparison except for the 16S rRNA sequence analysis has been made between $M$. haemomuris (synonym of 'H. muris') and other members of Mycoplasma sp. The members of the class Mollicutes have only one or two operons for the rRNA genes [1]. The genes coding for rRNA molecules of the genus Mycoplasma are organized in operons and arranged in the order of 5'-16S-23S-5S-3', in which the individual rRNA genes are separated by internal transcribed spacer (ITS) regions [14]. The ITS region between the $16 \mathrm{~S}$ and 23S rRNA genes of mycoplasmas has been shown to lack tRNA genes and to be variable in sequence and length depending on the Mycoplasma species [22]. Besides, the ITS region between the $16 \mathrm{~S}$ and $23 \mathrm{~S}$ rRNA genes has been used as a genetic marker for comparing phylogenetic relationships of genetically closely related species among not only the mycoplasmas $[4,7,18]$, but also other bacterial species $[2,6,9,20]$. Therefore, analyses of the ITS region may provide useful information for defining the genealogical position of the species of M. haemomuris.

In the present study, we sequenced and analyzed the ITS region between the $16 \mathrm{~S}$ and $23 \mathrm{~S}$ rRNA genes of $M$. haemomuris and compared it with those of genealogically related Mycoplasma species.

Bacterial genome DNA was isolated from the spleen cells of mice infected with $M$. haemomuris strain Shizuoka. PCR amplification of the isolated DNA was carried out at $94^{\circ} \mathrm{C}$ for $30 \mathrm{sec}, 55^{\circ} \mathrm{C}$ for $2 \mathrm{~min}$, and $72^{\circ} \mathrm{C}$ for $2 \mathrm{~min}$ for 30 cycles using forward (5'-ACACCATGGGAGYTGGTAAT-3') and reverse (5'-CTTCWTCGACTTYCAGACCCAAG GCAT-3') primers as described previously [3]. A single band of approximately $250 \mathrm{bp}$ was observed for the PCR products in agarose gel electrophoresis. The PCR product was then subjected to direct sequencing by the di-deoxynucleotide chain-termination method [16]. The nucleotide sequence determined in this study has been deposited in the DDBJ, EMBL, GSDB, and NCBI nucleotide sequence databases under the accession number AB080799.

The nucleotide sequence of the 16S-23S rRNA ITS of $M$. haemomuris was compared with those of other Mycoplasma species. The Mycoplasma species have been clustered into five groups according to the $16 \mathrm{~S}$ rRNA sequences [23]. Five species, $M$. hominis, $M$. arginini, $M$. salivarium, $M$. arthritidis and $M$. orale, have been included in the $M$. hominis group. Mycoplasma pneumoniae, M. fermentanss and $M$. mycoides subsp. mycoides represent the $M$. pneumoniae, M. fermentans and $M$. mycoides groups, respectively. Mycoplasma hyorhinis and $M$. neurolyticum are from the $M$. hyorhinis group. Three murine Mycoplasma species, $M$. pulmonis, $M$. arthritidis and $M$. neurolyticum, were included in this analysis, since $M$. haemomuris is also a murine isolate. Ureaplasma cati was included as an out group for phylogenetic analysis. The ITS of M. haemomuris was found to be 219 nucleotides. This sequence was aligned with those of the eleven Mycoplasma species (Fig. 1). Genealogical relatedness between $M$. haemomuris and other mycoplasmas was obtained by the neighbor-joining method [17]. The tree analysis suggests a monophyletic relationship between $M$. pneumoniae and M. haemomuris (Fig. 2). We examined the secondary structure of the ITS of M. haemomuris. Computer analysis indicated a hypothetical secondary structure of RNA transcript of the ITS region of $M$. 

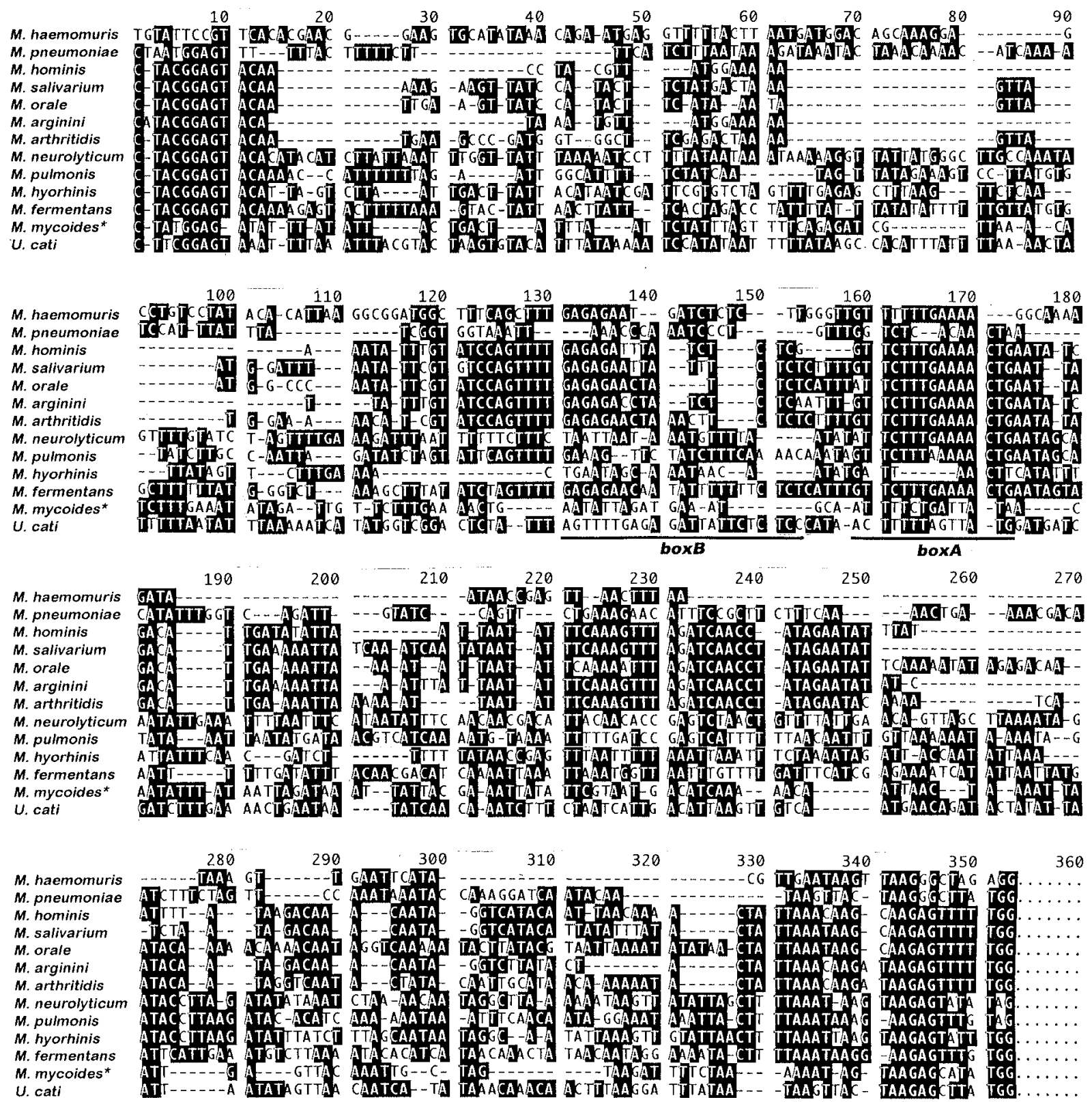

Fig. 1. Nucleotide sequence alignment of the 13 species including M. haemomuris. The nucleotide sequence numbers are given from a consensus sequence. Homologous nucleotides are shown as inverted characters. Dashes indicate nucleotide gaps between adjacent nucleotides introduced for the alignment. M. mycoides* represents $M$. mycoides subsp. mycoides.

haemomuris (Fig. 3). Tentative box $\mathrm{A}$ and box $\mathrm{B}$ loci [5] were assigned to the secondary structure. The box $\mathrm{A}$ and box $\mathrm{B}$, originally found at upstream regions of the nut site of the lambda phage genome, are considered to be the $\rho$-independent terminators [10]. The function of these sequences remains to be determined. No spacer tRNA gene was found within the ITS, and this is a common feature with those of the other species of the genus Mycoplasma [22].

In conclusion, the ITS of $M$. haemomuris lacked spacer tRNA genes and had boxA and boxB loci which are com- mon features of the Mycoplasma genome. Phylogenetic analysis indicated a monophyletic relationship between $M$. haemomuris and $M$. pneumoniae. These findings on $M$. haemomuris also support its classification as a member of the genus Mycoplasma.

ACKNOWLEDGEMENTS. We thank Prof. Hiroshi Nagatomo of the Faculty of Agriculture, Miyazaki University, for critical reading of the manuscript and for valuable comments. 


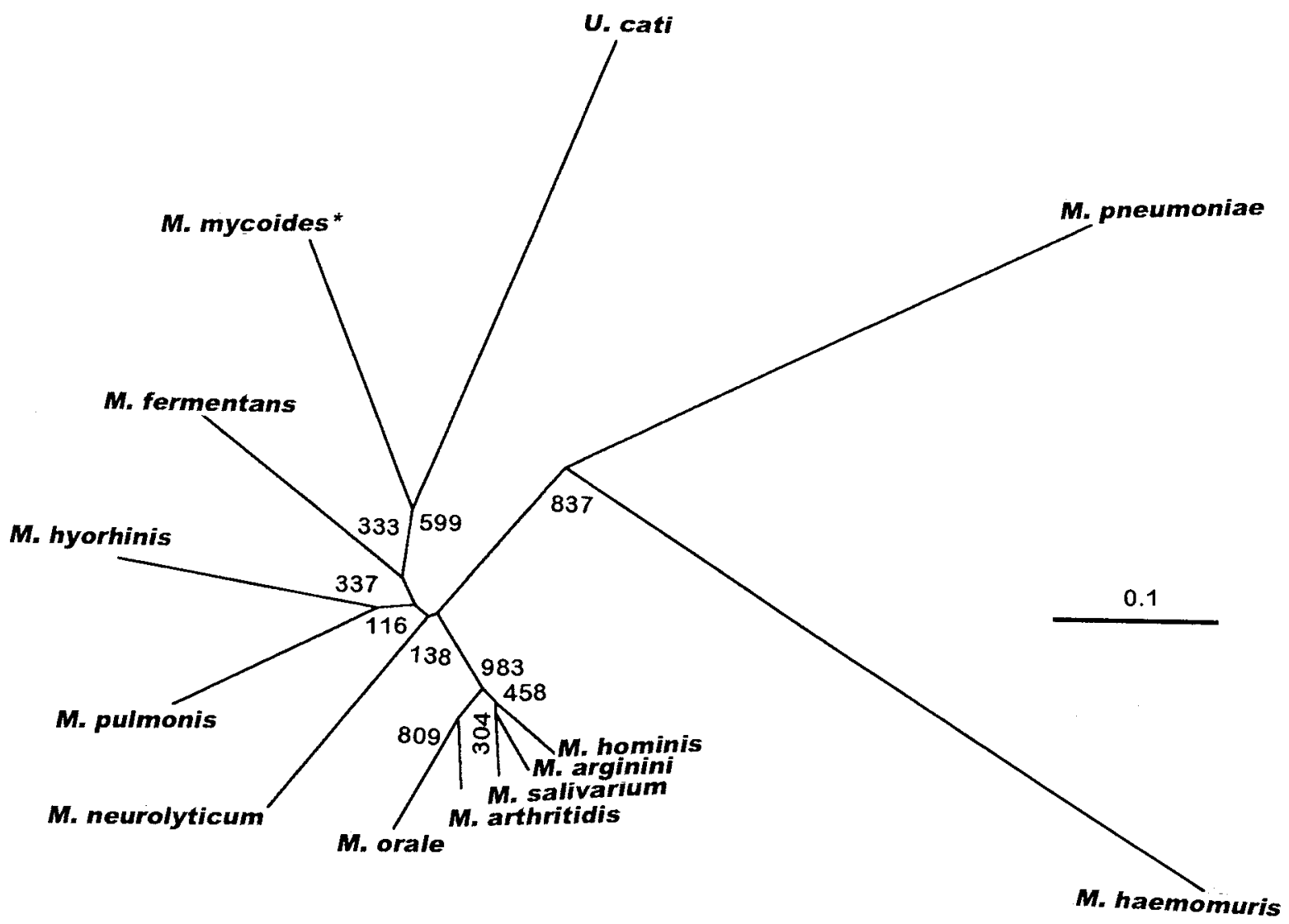

Fig. 2. Phylogenetic tree based on the ITS comparison, suggesting a monophyletic relationship betweenM. haemomuris and M. pneumoniae among the twelve Mycoplasma species examined. Evolutionary distances were computed with CLUSTAL W [21] using the neighbor-joining method [16]. Numbers at the relevant branches refer to the values of boot-strapping analysis of 1,000 replicati ons. Scale bar indicates the evolutionary distance value of 0.1 (ca. 10-nucleotide substitutions per 100 nucleotides). M. mycoides ${ }^{*}$ represents M. mycoides subsp. mycoides.

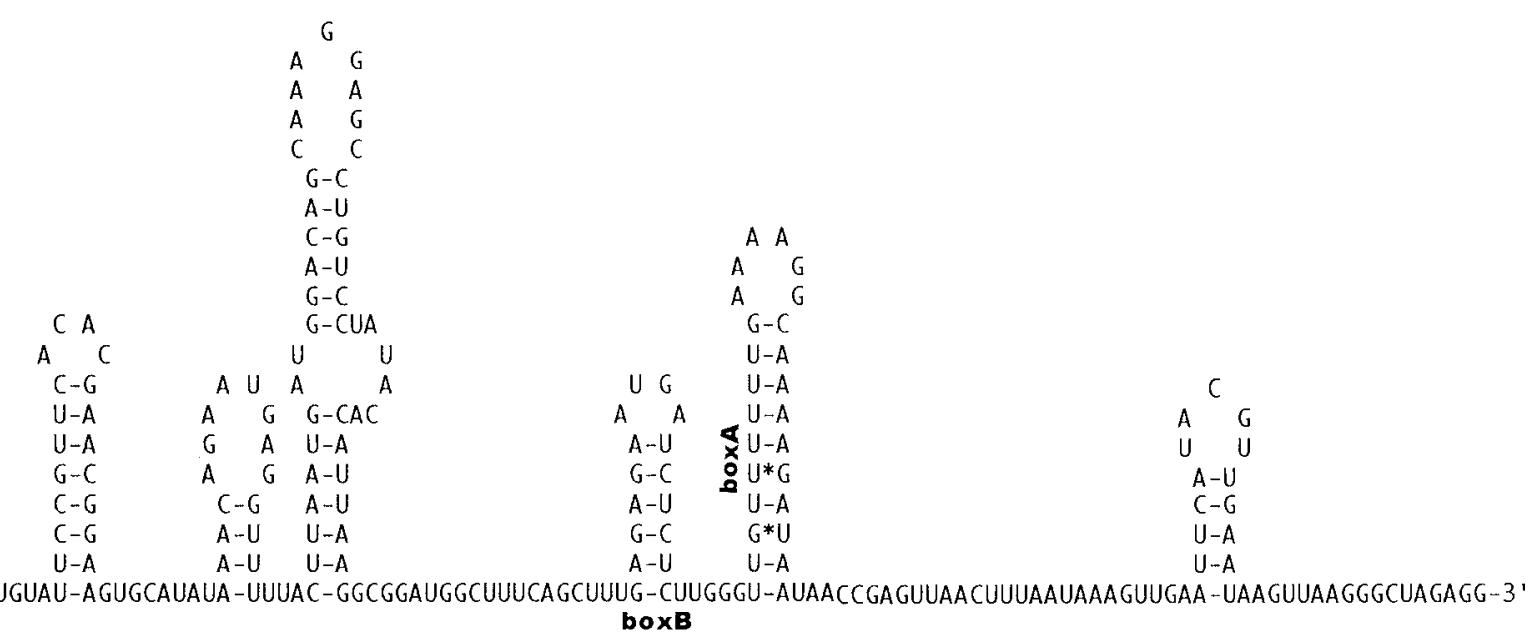

Fig. 3. Computed secondary structure for the ITS of M. haemomuris. BoxA and boxB loci are indicated in the figure. Canonical basepairing is hyphened, and uncanonical base-pairing is shown by asterisks. 


\section{REFERENCES}

1. Amikam, D., Glaser, G. and Razin, S. 1984. J. Bacteriol. 158: 376-378.

2. Graham, T. A., Golsteyn-Thomas, E. J., Thomas, J. E. and Gannon, V. P. J. 1997. Int. J. Syst. Bacteriol. 47: 863-869.

3. Harasawa, R. 1996. pp. 75-79. In: Molecular and Diagnostic Procedures in Mycoplasmology, vol. 2 (Razin, S. and Tully, J.G. eds.), New York: Academic Press.

4. Harasawa, R., Lefkowitz, E.J., Glass, J.I. and Cassell, G.H. 1996. J. Vet. Med. Sci. 58: 191-195.

5. Harasawa, R., Uemori, T., Asada, K., Kato, I. and Shiragami, N. 1992. FEBS Lett. 297: 209-211.

6. Jagoueix, S., Bove, J. M. and Garnier, M. 1997. Int. J. Syst. Bacteriol. 47: 224-227.

7. Kirkpatrick, B., Smart, C., Gardner, S., Gao, J.-L., Ahrens, U., Maurer, R., Schneider, B., Lorenz, K.-H., Seemuler, E., Harrison, N., Namba, S. and Daire, X. 1994. IOM Lett. 3: 228-229.

8. Kreier, J.P. and Ristic, M. 1984. pp. 724-729. In: Bergey's Manual of Systematic Bacteriology, vol. 1 (Krieg, N.R. and Holt, J.G. eds.), Baltimore, MD: Williams and Wilkins.

9. Leblond-Bourget, N., Philippe, H., Mangin, I. and Decaris, B. 1996. Int. J. Syst. Bacteriol. 46: 102-111.

10. Mankin, A.S., Skripkin, E.A. and Kagramonova, V.K. 1987. FEBS Lett. 219: 269-273.

11. Neimark, H., Johansson, K.-E., Rikihisa, Y. and Tully, J.G. 2001. Int. J. Syst. Evol. Microbiol. 51: 891-899.
12. Neimark, H., Johansson, K.-E., Rikihisa, Y. and Tully, J.G. 2002. Int. J. Syst. Evol. Microbiol. 52: 683.

13. Neimark, H. and Kocan, K.M. 1997. FEMS Microbiol. Lett. 156: $287-291$.

14. Razin, S. 1985. Microbiol. Rev. 49: 419-455.

15. Rikihisa, Y., Kawahara, M., Wen, B., Kociba, G., Fuerst, P., Kawamori, F., Suto, C., Shibata, S. and Futohashi, M. 1997. J. Clin. Microbiol. 35: 823-829.

16. Saitou, N. and Nei, M. 1987. Mol. Biol. Evol. 4: 406-425.

17. Sanger, F., Nicklen, S. and Coulson, A. R. 1977. Proc. Natl. Acad. Sci. U.S.A. 74: 5463-5467.

18. Smart, C., Sears, B. and Kirkpatrick, B. 1994. IOM Lett. 3: 269-270.

19. Tanaka, H., Hall, W. T., Sheffield, J.B. and Moore, D.H. 1965. J. Bacteriol. 90: 1735-1749.

20. Thain, T., Ward-Rainey, N., Kroppenstedt, R. M., Stackebrandt, E. and Rainey, F.A. 1997. Int. J. Syst. Bacteriol. 47: 202-206.

21. Thompson, J.D., Higgins, D.G. and Gibson, T.J. 1994. Nucleic Acids Res. 22: 4673-4680.

22. Uemori, T., Asada, K., Kato, I. and Harasawa, R. 1992. Syst. Appl. Microbiol. 15: 181-186.

23. Weisburg, W.G., Tully, J.G., Rose, D.L., Petzel, J.P., Oyaizu, H., Yang, D., Mandelco, L., Sechrest, J., Lawrence, T.G., Van Etten, J., Maniloff, J. and Woese, C.R. 1989. J. Bacteriol. 171: 6455-6467. 